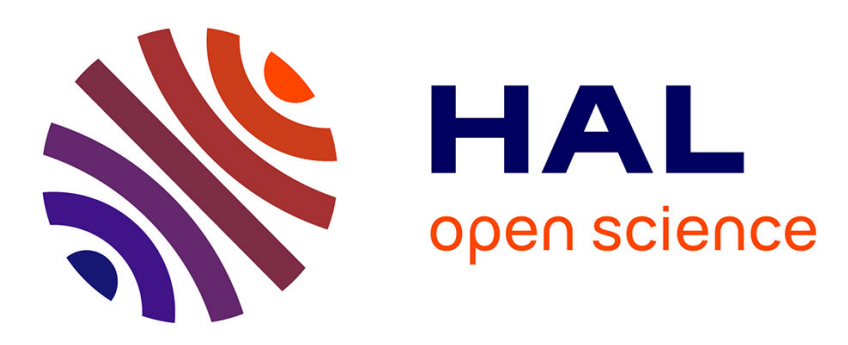

\title{
Composition of the volatile oil from the leaves of Ximenia americana $L$
}

Jean-Philippe Mevy, Jean-Marie Bessière, Stephane Greff, Gérard Zombre, Josette Viano

\section{- To cite this version:}

Jean-Philippe Mevy, Jean-Marie Bessière, Stephane Greff, Gérard Zombre, Josette Viano. Composition of the volatile oil from the leaves of Ximenia americana L. Biochemical Systematics and Ecology, 2006, 34 (7), pp.549 - 553. 10.1016/j.bse.2006.01.007 . hal-01764236

\section{HAL Id: hal-01764236 \\ https://hal-amu.archives-ouvertes.fr/hal-01764236}

Submitted on 11 Apr 2018

HAL is a multi-disciplinary open access archive for the deposit and dissemination of scientific research documents, whether they are published or not. The documents may come from teaching and research institutions in France or abroad, or from public or private research centers.
L'archive ouverte pluridisciplinaire HAL, est destinée au dépôt et à la diffusion de documents scientifiques de niveau recherche, publiés ou non, émanant des établissements d'enseignement et de recherche français ou étrangers, des laboratoires publics ou privés. 


\title{
Composition of the volatile oil from the leaves of Ximenia americana L.
}

\author{
Jean-Philippe Mevy ${ }^{\mathrm{a}, *}$, Jean-Marie Bessiere ${ }^{\mathrm{b}}$, Stéphane Greff ${ }^{\mathrm{c}}$, \\ Gérard Zombre ${ }^{\mathrm{d}}$, Josette Viano ${ }^{\mathrm{a}}$ \\ a Laboratoire de Dynamique et Ressources du Végétal EA 2202, UFR DENTES \& SVTE, Université de Provence, \\ 3 place Victor Hugo, 13331 Marseille, France \\ ${ }^{\mathrm{b}}$ Ecole Nationale Supérieure de Chimie, 8 rue école normale, 34296 Montpellier, France \\ ${ }^{\mathrm{c}}$ Laboratoire Biosystématique et Ecologie Méditerranéenne, Université de Provence, Faculté de Saint Jérôme-case 421 bis, \\ IMEP UMR 6116, Avenue Escadrille Normandie Niémen, 13397 Marseille, France \\ ${ }^{\mathrm{d}}$ Laboratoire de Biologie et d'Ecologie Végétales, Université de Ouagadougou, 03 BP 7021 Ouagadougou 03, Burkina Faso
}

\begin{abstract}
The volatile oil of leaves of Ximenia americana was analysed by GC-MS, which resulted in the identification of 33 components representing $98 \%$ of the total oil. The major constituents identified were benzaldehyde (63.5\%), hydroxybenzyl cyanide (13\%) and isophorone (3.5\%). Hydroxybenzyl cyanide is known as a primary breakdown product of glucosinolates that occur mainly in members of Brassicaceae family. The HPLC analysis carried out failed to confirm the possible synthesis or accumulation of glucosinolates in X. americana. Hence, the occurrence of hydroxybenzyl cyanide as well as that of benzaldehyde is discussed in this paper.
\end{abstract}

Keywords: Volatile oil; GC-MS; Ximenia americana; Benzaldehyde; Hydroxybenzyl cyanide; Isophorone; Glucosinolates

\section{Introduction}

Ximenia americana $\mathrm{L}$. is a shrub or a small tree of the family Olacaceae which is found in the tropical regions of America and Africa (Hutchinson and Dalziel, 1954). In folk medicine, a number of therapeutic uses of all parts of $X$. americana were reported; roots are employed as antiseptic, for mental diseases, fever, jaundice and headache, whereas the leaves are used for measles, toothache and also as laxative (Omer and Elimina, 2003; Sofowora, 1982). The pulverized bark is used as remedy for ulcers and the infusion of fruit is applied for bloody diarrhoea (Hutchinson and Dalziel, 1954). This plant acts also against rheumatism, cancer and mouth infections (Kokwaro, 1976; Chhabra and Uiso, 1990).

\footnotetext{
* Corresponding author. Current address: Laboratoire Biosystématique et Ecologie Méditerranéenne, Université de Provence, Faculté de Saint Jérôme-case 421 bis, IMEP UMR 6116, Avenue Escadrille Normandie Niémen, 13397 Marseille, France. Tel.: +33 491 288874 ; fax: +33 491 288707.

E-mail address: jean-philippe.mevy@up.univ-mrs.fr (J.-P. Mevy).
} 
Because of its medicinal properties, the phytochemistry of $X$. americana has been investigated by several authors. In root extracts, an oleanolic acid saponin was identified (D'Agostino et al., 1994) as well as $C_{18}$ acetylenic fatty acids (Fatope et al., 2000) and phenolic compounds (Mwangi et al., 1994). As far as investigation of our literature could ascertain, the chemical composition of leaves has been rarely investigated except for the early work that reported the presence of the cyanogenic glucoside, sambunigrin (Hutchinson and Dalziel, 1954). This prompted us to study the volatile fraction of the leaves of X. americana.

\section{Material and methods}

\subsection{Plant materials}

The aerial parts of X. americana were collected randomly in September (2000) at $\sim 30 \mathrm{~km}$ from Ouagadougou (Burkina-Faso) and authenticated by Dr J. Millogo. A voucher specimen is kept in the herbarium of the University of Aix-Marseille-I (ref. Mar-2004-41).

\subsection{Hydrodistillation}

The leaves were air-dried at room temperature, crushed and then subjected to hydrodistillation through a conventional Clevenger-type apparatus for $2 \mathrm{~h}$. The volatile oils were isolated three times from $3 \times 100 \mathrm{~g}$ of dry leaves.

\subsection{GC-MS analyses of the volatile constituents}

GC-MS analyses of the volatile oil were performed with a Hewlett-Packard 5972 capillary GC-quadrupole MS system, fitted with a fused silica column $(25 \mathrm{~m} \times 0.2 \mathrm{~mm} ; 0.15 \mu \mathrm{m}$ film thickness $)$ coated with DB5. The ionization energy was $70 \mathrm{eV}$. Helium was used as carrier gas with a flow rate of $1 \mathrm{ml} \mathrm{min}{ }^{-1}$. The oven temperature was set at $60{ }^{\circ} \mathrm{C}$ for $3 \mathrm{~min}$ then programmed from $60{ }^{\circ} \mathrm{C}$ to $220{ }^{\circ} \mathrm{C}$ at $3{ }^{\circ} \mathrm{C} \mathrm{min}{ }^{-1}$. Different components were identified by published mass spectra database and retention indexes (Adams, 1995; Jennings and Shibamoto, 1980). Computer searches in HP mass spectral library were also applied. The relative amount (RA) of each oil component is expressed as percent peak area relatively to the total peak area.

\subsection{HPLC analysis of glucosinolates}

Lyophylisated leaves and seeds of X. americana (200 mg) were soaked in $2 \mathrm{ml}$ of boiling $\mathrm{MeOH}-\mathrm{H}_{2} \mathrm{O}(7: 3)$ for $5 \mathrm{~min}$. The glucosinolates were extracted, purified on a DEAE Sephadex A-25, desulphated by a reaction with an arylsuphatase. The desulphated glucosinolates were then separated on an RP column of Spherisorb ODS 2 $\left(250 \times 4.6 \mathrm{~mm}, 5 \mu \mathrm{m}\right.$ particle size) with an elution gradient (from 0 to $25 \%$ of $\mathrm{MeCN}$ in $\mathrm{H}_{2} \mathrm{O}$ ). The quantification was carried out by UV spectrophotometry at $229 \mathrm{~nm}$ and the desulphoglucosinolates were identified according to their UV spectra and their capacity factors (Quinsac, 1993). The analyses were repeated in duplicate independent experiments.

\section{Results and discussion}

The volatile oils of the leaves of $X$. americana were obtained by hydrodistillation in a yield of $0.027 \%$ (relatively to dry weight material). The GC-MS analyses indicated that this oil is a complex mixture of 33 identified constituents which represent about $98 \%$ of the total oil (Table 1). This oil is made up of $69 \%$ of aromatic compounds, $12.5 \%$ of lipidic compounds, and $13 \%$ of terpenoid constituents. Benzaldehyde is by far the dominant molecule (63.5\%). The occurrence of different cyanogenic glycosides in leaves of $X$. americana has been reported earlier, among these, sambunigrin was shown as the most abundant component (Hutchinson and Dalziel, 1954). Accordingly, other workers have characterized a mandelonitrile lyase which catalyses the dissociation of the aglucone $(S)$-mandelonitrile to benzaldehyde and hydrogen cyanide (Kuroki and Conn, 1989) but these breakdown products may also be produced nonenzymatically in acid and elevated temperature conditions (Conn, 1980). As we checked, the hydrodistillations were 
Table 1

Composition of the volatile oil from the leaves of Ximenia americana

\begin{tabular}{|c|c|c|}
\hline Compound & $\mathrm{RI}^{\mathrm{a}}$ & $\% \mathrm{RA}^{\mathrm{b}}$ \\
\hline (Z)-Hexen-3-ol & 867 & 0.6 \\
\hline (E)-2-Hexenol & 874 & 0.1 \\
\hline 4-Methylpentanol & 875 & 0.6 \\
\hline Benzaldehyde & 936 & 63.5 \\
\hline 6-Methylhept-6-en-2-one & 966 & 1.0 \\
\hline$(E, E)-2,4$-Heptadienal & 971 & 0.6 \\
\hline Isophorone & 1042 & 3.5 \\
\hline 3,5-Octadien-2-one ${ }^{\mathrm{d}}$ & 1052 & 0.4 \\
\hline trans-Linalool oxide & 1065 & 0.8 \\
\hline Methyl benzoate & 1076 & 0.5 \\
\hline cis-Linalool oxide & 1081 & 1.6 \\
\hline 6-Methylhepta-3,5-dien-2-one & 1088 & 0.3 \\
\hline 3-Oxa-2,2,4-trimethyl-4-vinylcyclohexanone & 1093 & 1.0 \\
\hline Linalool & 1098 & 2.3 \\
\hline Terpinen-4-ol & 1184 & 0.1 \\
\hline$\alpha$-Terpineol & 1197 & 1.7 \\
\hline$\beta$-Cyclocitral & 1224 & 0.2 \\
\hline Allyl hexanoate & 1247 & 0.2 \\
\hline Geraniol & 1277 & 0.2 \\
\hline Hydroxybenzyl cyanide & 1322 & 13.0 \\
\hline$(2 E, 4 E)$-Nonadienal & 1337 & 0.2 \\
\hline Geranyl acetone & 1452 & 0.6 \\
\hline Epoxy- $\beta$-ionone & 1473 & 0.3 \\
\hline$\beta$-Ionone & 1477 & 0.3 \\
\hline Dihydroactinidiolide & 1493 & 0.1 \\
\hline Actinidiolide & 1496 & 0.3 \\
\hline $\mathrm{NI}^{\mathrm{c}}$ & 1506 & 1.3 \\
\hline (Z)-3-Hexenyl benzoate & 1508 & 0.2 \\
\hline Caryophyllene oxide & 1581 & 0.4 \\
\hline Humulene oxide II & 1606 & 0.2 \\
\hline$\gamma$-Eudesmol & 1633 & 0.2 \\
\hline Campherenone & 1642 & 0.5 \\
\hline$\beta$-Eudesmol & 1647 & 0.6 \\
\hline$\alpha$-Eudesmol & 1653 & 0.5 \\
\hline Total identified & & 97.9 \\
\hline
\end{tabular}

\footnotetext{
${ }^{a}$ Retention index.

b Relative area.

c Not identified.

${ }^{\mathrm{d}}$ Stereochemistry not determined.
}

carried out in acid conditions ( $\mathrm{pH}=5.53)$, suggesting that the high content of benzaldehyde found in the leaves of $X$. americana may be correlated with the presence of sambunigrin.

The second main constituent found is hydroxybenzyl cyanide (13\%). 2-, 3- and 4-hydroxybenzyl cyanides are listed among the breakdown products of glucosinolates (Fahey et al., 2001). The latter compounds are mainly found in members of Brassicaceae family where they co-exist with myrosinase. Because the non-enzymatic thermal degradation of glucosinolates may yield components that are identical to those of the conventional enzymatic hydrolysis (MacLeod and Rossiter, 1986), our data raise the question of the occurrence of intact glucosinolates in the whole plant of $X$. americana. Lyophylisated leaves were analysed by HPLC but no glucosinolates were identified. Further studies were carried out from seed materials since these constitute a particularly rich source of glucosinolates (Fenwick et al., 1983). The HPLC analysis results in an absence of glucosinolates above the detection threshold of the method used; $0.1 \mu \mathrm{g} / \mathrm{g}$ of seed. The traces obtained may be interpreted either as minor components which chromatographic properties are similar to those of glucosinolates or as the result of the contamination of our samples with extracts of the routinely analysed glucosinolate-containing plant materials. Accordingly, the presence of hydroxybenzyl cyanide in the leaves of $X$. americana is rather the fact of the addition of cyanure ions to benzaldehyde. This classical reaction may have occurred during the hydrodistillation of leaf materials in aqueous acid medium. 
Our results raise the question of the original (in situ) flavour components of X. americana because under hydrodistillation conditions, the oil is boiled out after placing plant material into water. This often leads to $\mathrm{pH}$ changes and chemical rearrangements of oil components as clearly shown in a comparative study of cedar wood oil extraction through hydrodistillation and stream distillation (Adams, 1991). In order to check whether benzaldehyde and hydrobenzyl cyanide were actual volatile oil components, solvent extracts in diethyl ether and pentane were analysed. None of these components were detected in the extracts which confirm their occurrence as artifact due to hydrodistillation.

The norisoprenoid, isophorone was identified in leaves of $X$. americana in a rate of 3.5\%. This compound was shown as a carcinogenic agent (Their et al., 1990; Bucher et al., 1986) which seems to be in contradiction with the traditional use of the plant in cancer treatment. As reported, many compounds may exhibit both carcinogenic and anticarcinogenic effects (Kohlmeier et al., 1995) but it is not excluded that the occurrence of compounds other than volatile constituents may act in the anticarcinogenic process.

Among the minor constituents found in this oil, it should be noted that several of them such as $\beta$-cyclocitral, $\beta$-ionone and actinidiolide are carotenoid derivatives as well as isophorone.

In conclusion, this study reveals that the volatile oil constituents of leaves of $X$. americana may vary significantly depending on the conditions of extraction. The Olacaceae family comprises 28 genera among which 13 are monospecific. Olacaceae are paraphyletic, a cladistic approach led to the identification of four lineages and the genus Ximenia (tribe Ximenieae) belongs to clade 2, together with genera Curipira, Douradoa and Malania (Malecot et al., 2004). Few chemical investigations regarding the volatile oil composition of members of the family Olacaceae have been reported so far: Bucek et al. (1987) showed that the oil obtained from stream distillation of Ptychopetalum olacoides (clade 3 , tribe Olaceae) was mainly composed of $\alpha$-pinene, $\alpha$-humulene and $\beta$-pinene. New sesquiterpenes were isolated from Olacaceae, namely, scodopin (Wiart et al., 2001) from solvent extract of Scorodocarpus borneensis (clade 1, tribe Anacoloseae) and manicol (Banwell and Cameron, 1996) from Dulacia guianensis (clade 3, tribe Olaceae). None of the above-mentioned terpenic constituents was found in the volatile oil of X. americana. This suggests that isophorone may be of chemotaxonomic significance to the monotypic genus Ximenia which belongs to the tribe Ximenieae. Another question pointed out in this study is that surrounding the occurrence of chemicals identified as rodent carcinogens in plants used in folk medicine.

\section{Acknowledgments}

The author gratefully acknowledges Dr A. Quinsac and M. Krouti of the laboratory of CETIOM (Centre Technique des Oléagineux Métropolitains) for their assistance in glucosinolates analysis.

\section{References}

Adams, R.P., 1995. Identification of Essential Oils Components by Gas Chromatography/Mass Spectroscopy. Allured Publishing Co., Carol Stream, Illinois.

Adams, R.P., 1991. Cedar wood oil - analysis and properties. In: Linskens, H.F., Jackson, J.F. (Eds.), Modern Methods of Plant Analysis, New Series: Essential Oils and Waxes. Springer-Verlag, Berlin.

Banwell, M.G., Cameron, J.M., 1996. Enantiospecific construction of the carbon skeleton associated with manicol, an antineoplastic sesquiterpene from Dulacia guianensis (Olacaceae). Phytochemistry 37 (4), 525-526.

Bucek, E.U., Fournier, G., Dadoun, H., 1987. Volatile constituents of Ptychopetalum olacoides root oil. Planta Med. 53 (2), 231.

Bucher, J.R., Huff, J., Kluwe, W.M., 1986. Toxicology and carcinogenesis studies of isophorone in F344 rats and B6C3F1 mice. Toxicology 39 (2), 207-219.

Chhabra, S.C., Uiso, F.C., 1990. A survey of the medicinal plants of eastern Tanzania for alkaloids, flavonoids, saponins and tannins. Fitoterapia IXI (4), 307-316.

Conn, E.E., 1980. Cyanogenic glycosides. In: Pirson, A., Zimmermann, M.H. (Eds.), Encyclopedia of Plant Physiology. New Series, vol. 8. Springer-Verlag, Berlin/Heidelberg/New York.

D’Agostino, M., Biagi, C., De Simone, F., Pizza, C., 1994. An oleanolic acid saponin from Ximenia americana. Fitoterapia LXV (1), 59.

Fahey, J.W., Zalcmann, A.T., Talalay, P., 2001. The chemical diversity and distribution of glucosinolates and isothiocyanates among plants. Phytochemistry $56,5-51$.

Fatope, M.O., Adoum, O.A., Takeda, Y., 2000. $\mathrm{C}_{18}$ acetylenic fatty acids of Ximenia americana with potential pesticidal activity. J. Agric. Food Chem. 48, 1872-1874.

Fenwick, G.R., Heaney, R.K., Mullin, W.J., 1983. CRC Critical Reviews in Food Science and Nutrition 18 (2), $123-201$.

Hutchinson, J., Dalziel, J.M., 1954. Flora of West Tropical Africa. T. Nelson and Sons, London. 
Jennings, W., Shibamoto, T., 1980. Quantitative Analysis of Flavour and Fragrance Volatiles by Glass Capillary Gas Chromatography. Academic Press, New York.

Kohlmeier, L., Simonsen, N., Mottus, K., 1995. Dietary modifiers of carcinogenesis. Environ. Health Perspect. 103 (8), $177-184$.

Kokwaro, J.O., 1976. Medicinal Plants of East Africa. East African Literature Bureau, Nairobi, p. 167.

Kuroki, G.W., Conn, E.E., 1989. Mandelonitrile lyase from Ximenia americana L.: stereospecificity and lack of flavin prosthetic group. Proc. Natl. Acad. Sci. U.S.A. 86, 6978-6981.

MacLeod, A.J., Rossiter, J.T., 1986. Non-enzymic degradation of 2-hydroxybut 3-enylglucosinolate (progoitrin). Phytochemistry 25, 855-858.

Malecot, V., Nickrent, D.L., Bass, P., Oever, L.V.D., 2004. A morphological cladistic analysis of Olacaceae. Syst. Bot. 29 (3), $569-586$.

Mwangi, J.W., Malii, P., Gathu, L., Tanaka, T., Nonaka, G., 1994. Polyphenols of Ximenia americana var. caffra. Fitoterapia LVX (2), 185.

Omer, M.E.F.A., Elimina, E.I., 2003. Antimicrobial activity of Ximenia americana. Fitoterapia 74, 122-126.

Quinsac, A., 1993. Les glucosinolates et leurs derives dans les Cruciféres. Analyses par chromatographie en phase liquide et perspectives d'utilisation de l'électrophorèse capillaire. Thèse de Doctorat de l'Université d'Orléans.

Sofowora, A., 1982. Medicinal Plants and Traditional Medicine in Africa. John Wiley and Sons Limited, New York.

Their, R., Petre, H., Wiegand, H.J., Bolt, H.M., 1990. DNA binding study of isophorone in rats and mice. Arch. Toxicol. 64 (8), $684-685$.

Wiart, C., Martin, M.-T., Awang, K., Hue, N., Serani, L., Laprevote, O., Païs, M., Rhamani, M., 2001. Sesquiterpenes and alkaloids from Scorodocarpus borneensis. Phytochemistry 58, 653-656. 